\title{
A TRANSECT STUDY OF THE SAND DUNE VEGETATION AT BAKERS BEACH, TASMANIA
}

\author{
by M. A. Chladil and J. B. Kirkpatrick
}

(with three tables, five text-figures and three plates)

CHLADIL, M.A. \& KIRKPATRICK, J.B., 1989 (31:x): A transect study of the sand dune vegetation at Bakers Beach, Tasmania. Pap. Proc. R. Soc. Tasm. 123: 247-256. https://doi.org/10.26749/rstpp.123.247

ISSN 0080-4703. Department of Geography and Environmental Studies, University of Tasmania, GP Box 252C, Hobart, Tasmania, Australia 7001.

Vegetation zonation on coastal sand dunes at Bakers Beach consists of Spinifex hirsutus grassland, Helichrysum paralium-Acacia sophorae heath and a complex of Acacia sophorae heath with Lomandra longifolia herbland, the latter community being concentrated in the swales. Melaleuca ericifolia swamp forest occupies the drainage line to the rear of the sand dunes. Although the two seaward zones and the swamp forest may be in equilibrium with the environmental complex, the vegetation on the main body of the dunes has been degraded from its original state by clearing and stock grazing and shows evidence of shifting from its present condition towards communities dominated by Leucopogon parviflorus and Banksia marginata. Eucalyptus viminalis open-forest may have occupied much of this dune system in the past. Floristic variation along a transect through the dunes is closely related to edaphic and topographic conditions, supporting models of soil-vegetation relationships on sand dune systems that have been developed elsewhere in southeastern Australia.

Key Words: coastal vegetation, sand dunes, Tasmania.

\section{INTRODUCTION}

Some quantitative data are available on the vegetation of coastal sand dune sequences in southeastern Tasmania (Bowden \& Kirkpatrick 1974, Brown \& Bayley-Stark 1979, Kirkpatrick, in press) and southeastern Australia (Turner et al. 1962, Specht 1972, Ladd et al. 1976, Barson \& Calder 1981, Kirkpatrick, in press) but none are available for northern Tasmania. Other Tasmanian coastal areas have also been described (Stephens \& Cane 1939, Davis 1940, Kirkpatrick 1973, 1975, Brown 1980). As northern Tasmania was known to largely lack plant communities and species such as Leptospermum laevigatum and Banksia integrifolia that characterise sand dune systems of the humid southeastern Australian mainland (Kirkpatrick, in press), and was also known to have beach sands which are considerably more calcareous than those of southeastern Tasmania (Davies 1978), it was thought worthwhile to document the vegetation of one of its largest systems of parallel dunes, or beach ridges (Davies 1978) at Bakers Beach in Asbestos Range National Park (fig. 1). The study was conducted in May, August and September 1986. The pattern of variation in vegetation along a transect orthogonal to the beach is described, and the relationship between edaphic and topographic environmental variables and vegetation along this transect is examined. The past and likely future of the vegetation of this sand dune system are discussed.

\section{THE STUDY AREA}

Bakers Beach $\left(41^{\circ} 08^{\prime} \mathrm{S} 146^{\circ} 38^{\prime} \mathrm{E}\right)$ faces Bass Strait on Tasmania's mid-northern coast at the mouth of the Port Sorell estuary (fig. 1). The beach front is about $7 \mathrm{~km}$ long and has a dune system parallel to the beach front with a lagoon and wetlands behind.

The beach is located within Asbestos Range National Park (4281 ha) which was proclaimed in 1976. Prior to proclamation, the Park was mostly a grazing property; the lagoon and wetlands had been drained for improved pasture and the whole area subject to recurrent fires for "green pick" and to wildfires. Following proclamation, grazing stock were removed and the (convict built) drains filled. As the lagoon filled, the native animal population rapidly expanded. A wildfire burnt much of the dune system in 1978. The vegetation is recovering from the fire in the face of heavy grazing pressure from European rabbit (Oryctolagus cuniculus), common wombat (Vombatus ursinus) and Bennetts wallaby (Macropus rufogriseus).

The study area experiences a temperate maritime climate (National Parks \& Wildlife Service 
M. A. Chladil and J. B. Kirkpatrick

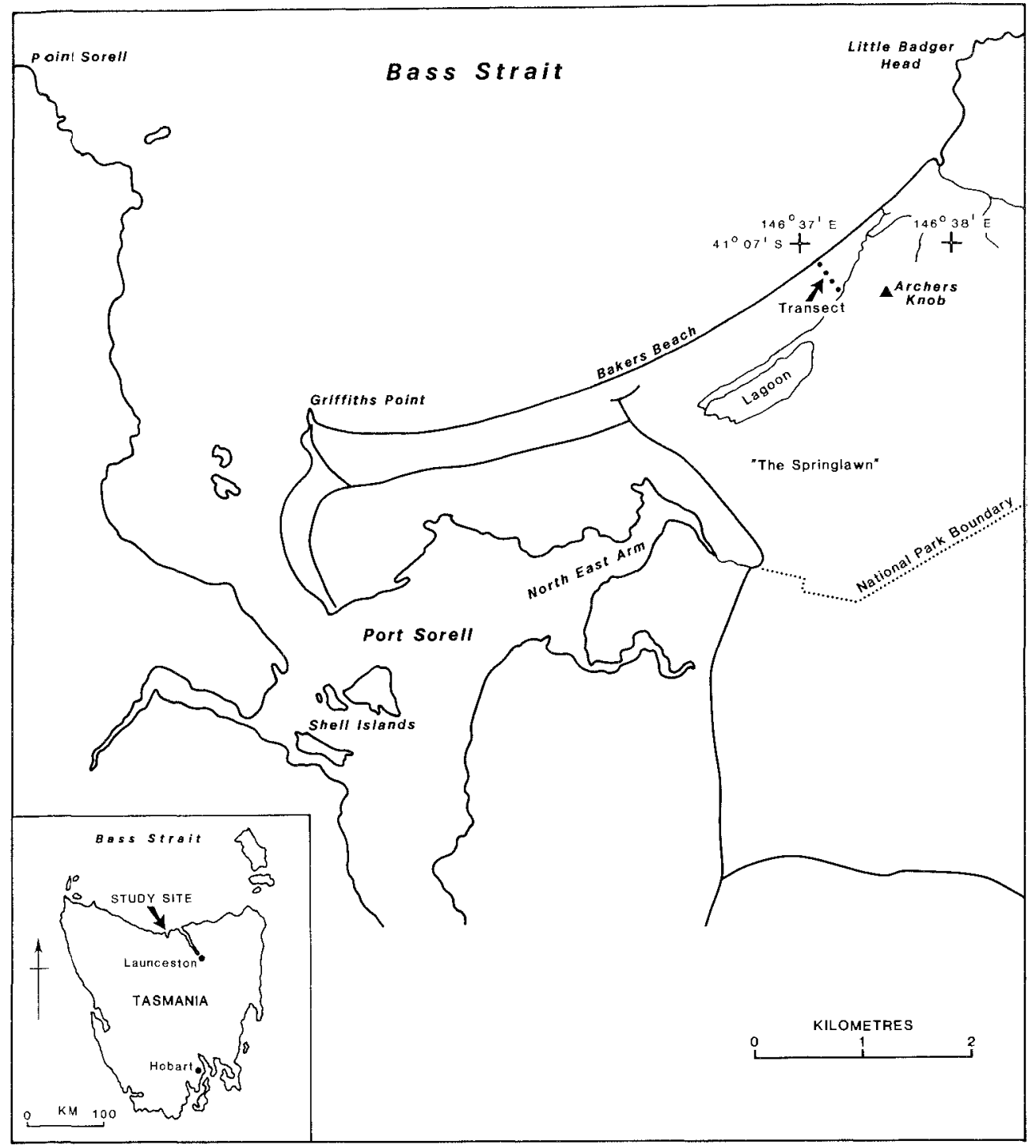

FIG. 1 - Location map.

\section{TABLE 1}

Selected Average Climatic Data for Low Head, Tasmania ( 28 m a.s.I.)

\begin{tabular}{lccccccccccccc}
\hline & $\mathbf{J}$ & $\mathbf{F}$ & $\mathbf{M}$ & $\mathbf{A}$ & $\mathbf{M}$ & $\mathbf{J}$ & $\mathbf{J}$ & $\mathbf{A}$ & $\mathbf{S}$ & $\mathbf{O}$ & $\mathbf{N}$ & $\mathbf{D}$ & Year \\
\hline $\begin{array}{l}\text { Rainfall }(\mathrm{mm}) \\
\text { Maximum }\end{array}$ & 37 & 38 & 42 & 55 & 68 & 80 & 80 & 71 & 60 & 60 & 41 & 46 & 683 \\
$\begin{array}{l}\text { temperature }\left({ }^{\circ} \mathrm{C}\right) \\
\text { Minimum }\end{array}$ & 20.0 & 20.4 & 19.1 & 16.8 & 14.3 & 12.3 & 11.7 & 12.1 & 13.2 & 14.6 & 16.6 & 18.5 & 15.8 \\
temperature $\left({ }^{\circ} \mathrm{C}\right)$ & 12.7 & 13.1 & 12.0 & 10.2 & 8.2 & 6.5 & 5.9 & 6.3 & 7.4 & 8.5 & 10.0 & 11.6 & 9.4 \\
\hline
\end{tabular}

Source: Bureau of Meteorology, 1979. 
(NPWS) 1979). The nearest weather station is at Low Head $16 \mathrm{~km}$ to the east. The annual rainfall is likely to be in the range $650-750 \mathrm{~mm}$, mostly falling in winter. Temperatures are mild, with a range at Low Head of $12.7^{\circ} \mathrm{C}$ to $20^{\circ} \mathrm{C}$ in January and $5.9^{\circ} \mathrm{C}$ to $11.7^{\circ} \mathrm{C}$ in July. Selected data are presented in table 1 (Bureau of Meteorology 1979).

The wind regime has close to a bimodal distribution: dry northwesterlies (mostly in summer) and moist southwesterlies (mostly in winter). The major fetch is to the west-northwest, making Bakers Beach a relatively high-energy part of the coast.

\section{METHODS}

At 25 sites located on dune ridges and swales along a surveyed transect placed orthogonally to the beach (fig. 1) the following data were collected: the percentage cover of all perceived higher plant species, moss and bare sand along $20 \mathrm{~m}$ line intercepts (Canfield 1941) laid along dune swales and ridges; soil horizon depth; $\mathrm{pH}$ (using a CSIRO soiltesting kit); Munsell colour; and depth of water table, where less than $2 \mathrm{~m}$. Soils were collected for later analysis of $\mathrm{CaCO}_{3}$, and organic matter content.

The qualitative vegetation data were classified using the polythetic divisive technique contained in the program TWINSPAN (Hill 1979) and were ordinated using detrended correspondence analysis (Hill \& Gauch 1980). Product moment correlation coefficients were used to test relationships between vegetation and environment. Swamp vegetation sites were excluded from some analyses.

Species nomenclature follows Curtis (1963, 1967), Curtis \& Morris (1975) and Willis (1970) except where authorities are given at first mention. Structural nomenclature follows Kirkpatrick \& Harwood (1983) for wetland communities and Specht (1970) for other communities.

\section{RESULTS AND DISCUSSION}

\section{Variation along the Transect}

Calcareous sands undifferentiated to depth characterise the two foremost dunes (table 2), the second of which is the tallest in the whole series $(12.5 \mathrm{~m})$. On these two dunes vegetation changes from Cakile ephemeral herbland at the rear of the beach to heavily-grazed Spinifex hirsutus open-grassland on the small foredune to a rich mixture of composite shrubs, scramblers (Tetragonia implexicoma and Rhagodia baccata) and Acacia sophorae on the second large dune (fig. 2, pl. 1).

The smaller ridges and swales to the rear of the foredune system have been topdressed by calcareous sands as a result of blowouts on the foredune. This narrow layer of calcareous sand is underlain by one, or sometimes two, weakly podsolised soil horizons. In this part of the dune system, swales are largely occupied by Pteridium

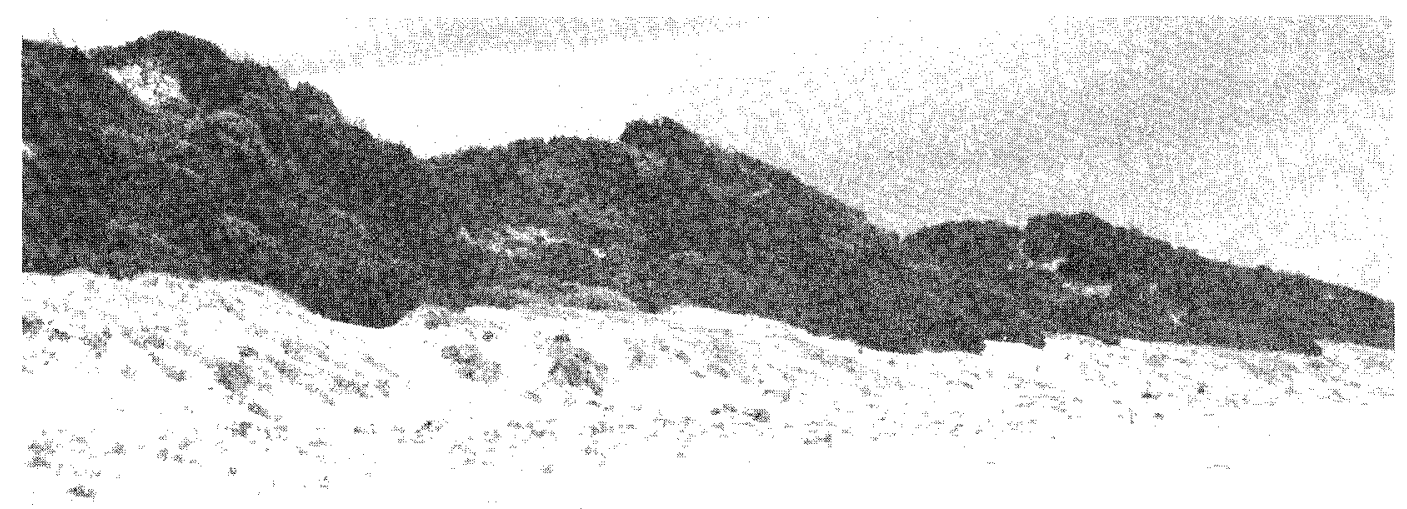




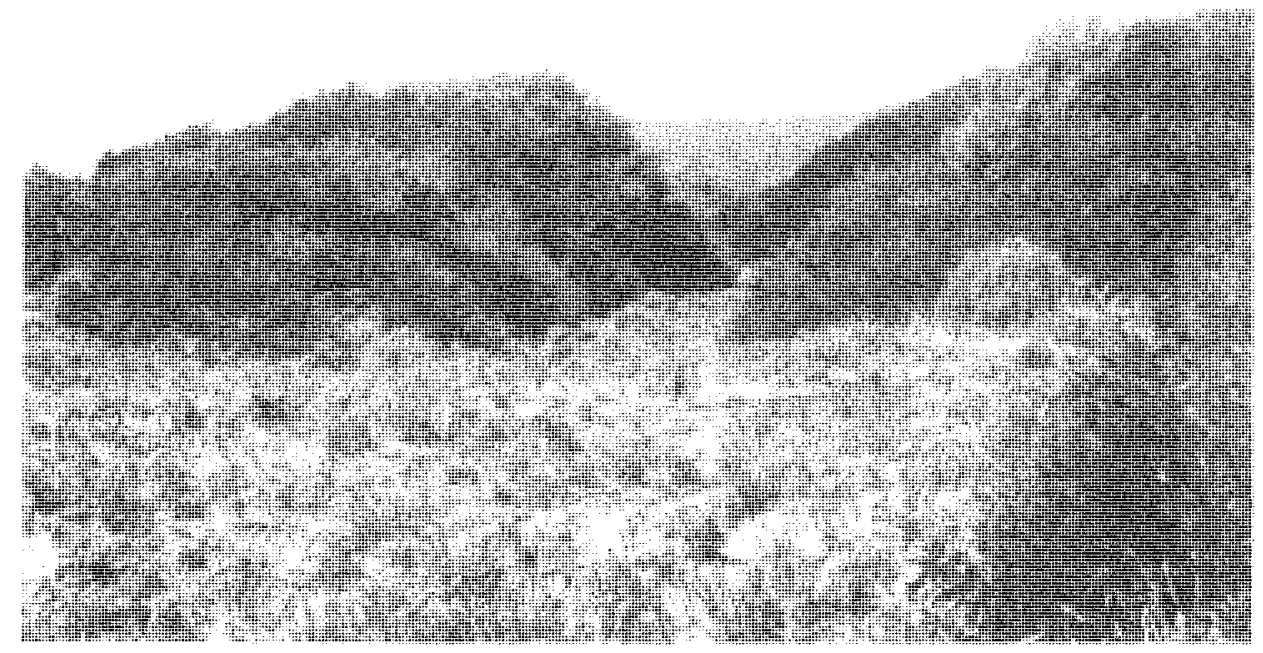

PLATE 2

Ridges dominated by Acacia sophorae and swale dominated by Lomandra longifolia.

TABLE 2

Surface Soil Properties Along the Transect at Bakers Beach

\begin{tabular}{lcccc}
\hline Sample* & $\begin{array}{c}\text { CaCO} \\
\%\end{array}$ & pH & $\begin{array}{c}\text { NaCl } \\
(\mathbf{p p m})\end{array}$ & $\begin{array}{c}\text { Organic content } \\
\%\end{array}$ \\
\hline D1 & 10.45 & 7.0 & 70 & 0.0 \\
D2 & 12.36 & 7.0 & 14.5 & 0.0 \\
D3 & 13.78 & 7.0 & 4 & 0.0 \\
D4 & 6.75 & 7.0 & 14 & 0.0 \\
D5 & 6.95 & 7.0 & 45 & 0.0 \\
R1 & 8.42 & 7.0 & 6.5 & 0.0 \\
S1 & 9.21 & 7.0 & 11 & 0.0 \\
R2 & 8.99 & 8.0 & 5.5 & 0.0 \\
S2 & 7.33 & 7.0 & 6 & 0.0 \\
R3 & 8.19 & 7.0 & 16 & 1.9 \\
S3 & 6.37 & 7.0 & 0 & 0.0 \\
R4 & 5.69 & 6.5 & 12 & 1.3 \\
S4 & 4.22 & 7.0 & 4 & 0.5 \\
R5 & 5.06 & 6.5 & 34.5 & 1.5 \\
S5 & 3.22 & 6.0 & 16.5 & 1.4 \\
R6 & 4.45 & 6.0 & 18 & 1.0 \\
S6 & 5.00 & 6.0 & 39.5 & 3.4 \\
R7 & 3.34 & 6.0 & 22 & 1.5 \\
S7 & 3.18 & 6.0 & 7 & 3.7 \\
R8 & 2.80 & 6.0 & 3.5 & 2.3 \\
M & 2.41 & 6.0 & 40 & 2.6 \\
E & 5.82 & 6.0 & 11 & 1.6 \\
\hline
\end{tabular}

* Swamp samples excluded 


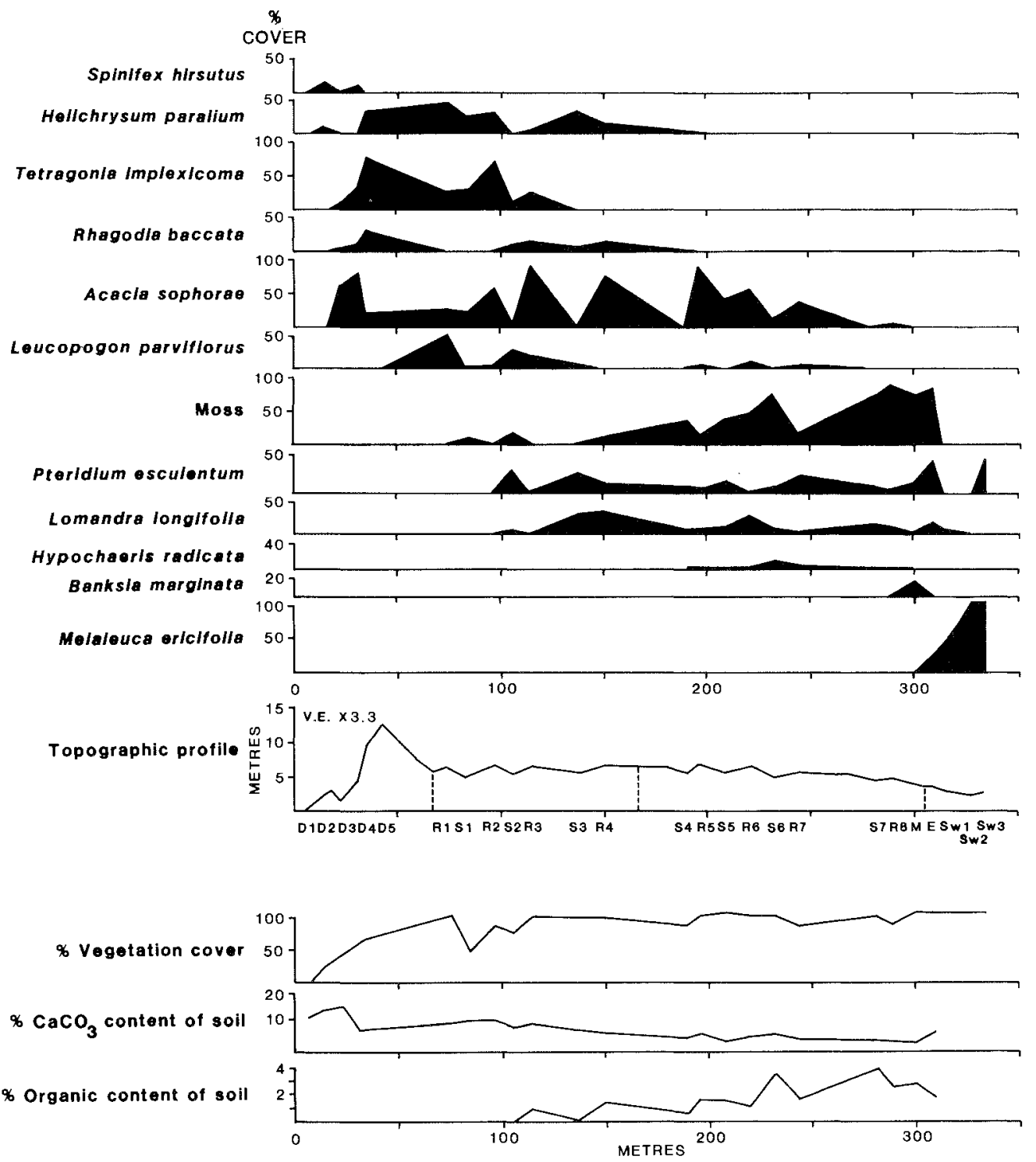

FIG. 2 - Percentage cover of selected species and variability in environmental attributes over the transect. 


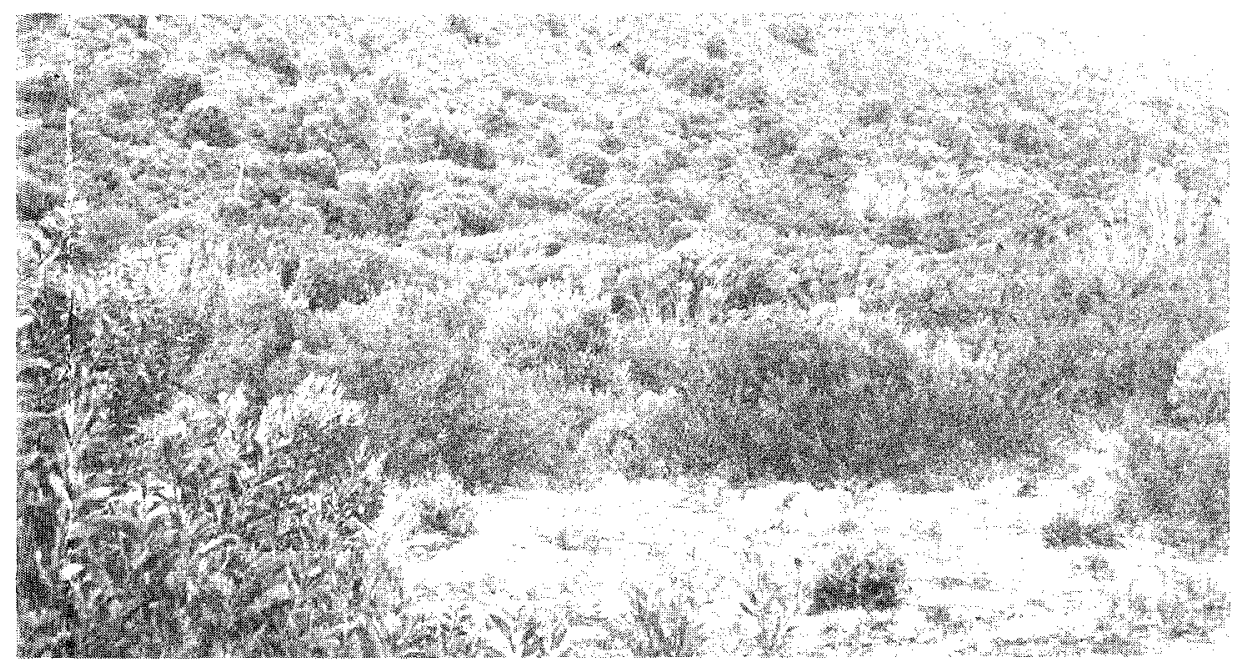

\section{PLATE 3}

The rear of the sand dune system, the swamp and the stranded cliff.

esculentum, Lomandra longifolia, small herbs and bare sand, while the ridges have vegetation similar to that of the second foredune with scramblers among composite shrubs and 1-2 $\mathrm{m}$ tall spreading Acacia sophorae (pl. 2).

The break between topdressed podsols and those without topdressing can be clearly perceived in the absence of scramblers and composite shrubs, in the presence of species such as Acaena echinata and Pimelea humilis and in the increased cover of moss (fig. 2, pl. 2). The rear dunes have the same pattern of shrub dominance on ridges and herb dominance in swales as is evident for the topdressed area (pl. 3). They are bounded by a swale with a species-poor $10 \mathrm{~m}$ tall Melaleuca ericifolia swamp forest to their rear. This forest abuts a quartzite cliff covered by scrub dominated by Casuarina stricta on its lower slopes and heath on its upper slopes (pl. 3).

\section{Vegetation-Environment Relationships along the Transect}

TWINSPAN classification clearly discriminated between the major vegetation units described above, and also between vegetation ridges and swales on the old sand at the rear of the sand dune system (table 3, fig. 3). The ordination scores on the first axis exhibit an exponential decline with

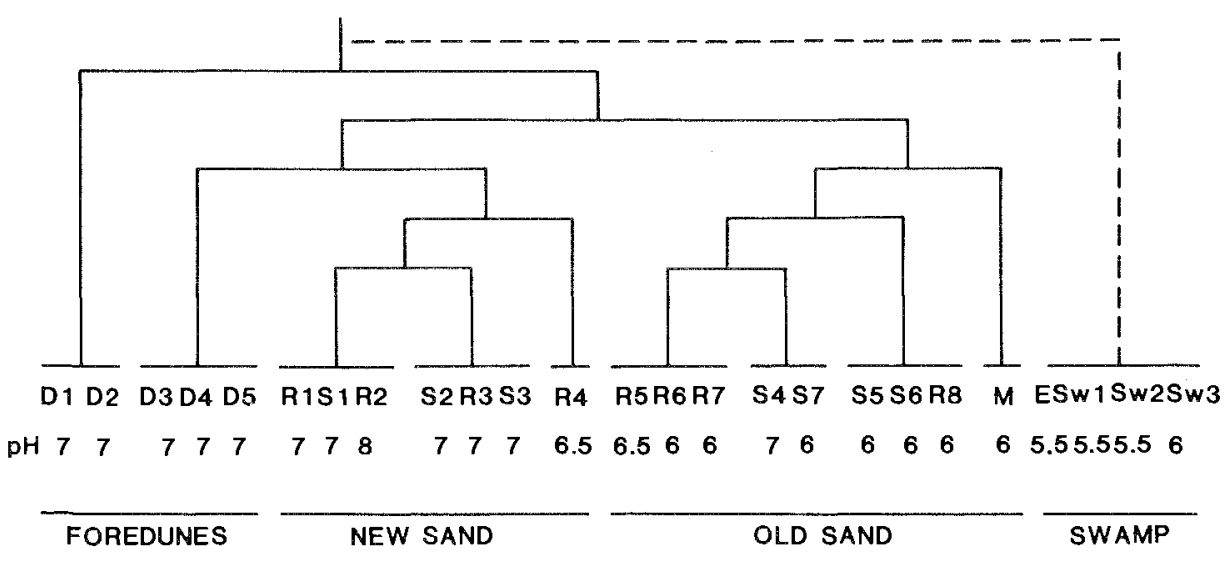

FIG. 3 - TWINSPAN classification of samples as related to $\mathrm{pH}$ and environment. 
TABLE 3

Percentage Frequency of Species by TWINSPAN Classification Groups

\begin{tabular}{|c|c|c|c|c|}
\hline Species & $\begin{array}{c}\text { Colonisers } \\
(n=5)\end{array}$ & $\begin{array}{c}\text { New sand } \\
(n=7)\end{array}$ & $\begin{array}{c}\text { Old sand } \\
(n=9)\end{array}$ & 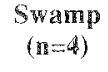 \\
\hline Spinifex hirsutus & 100 & - & $\cdots$ & - \\
\hline Cakile edentula & 20 & - & - & - \\
\hline Helichrysum paralium & 60 & 86 & 11 & - \\
\hline Acacia sophorae & 60 & 86 & 67 & - \\
\hline Tetragonia implexicoma & 60 & 71 & - & - \\
\hline Rhagodia baccata & 60 & 71 & $\ldots$. & - \\
\hline Acaena novae-zelandiae & 20 & - & - & - \\
\hline Oxalis corniculata & 20 & 100 & 67 & 25 \\
\hline Fumaria sp. & 20 & 86 & 33 & - \\
\hline Leucopogon parviflorus & 20 & 71 & 56 & 50 \\
\hline Stipa flavescens & 20 & 29 & - & - \\
\hline Carpobrotus rossii & 40 & 86 & 78 & - \\
\hline Pteridium esculentum & - & 100 & 100 & 50 \\
\hline Lepidosperma gladiatum & - & 29 & - & - \\
\hline Dichondra repens & - & 86 & 56 & 25 \\
\hline Graminae sp. & - & 57 & 22 & - \\
\hline Senecio minimus & - & 57 & - & - \\
\hline Lomandra longifolia & - & 71 & 100 & 50 \\
\hline Clematis microphylla & - & 14 & 22 & - \\
\hline Danthonia setacea & - & 14 & 78 & - \\
\hline Hypochaeris radicata* & - & - & 100 & - \\
\hline Coprosma quadrifida & - & - & 22 & - \\
\hline Acaena echinata & - & - & 78 & 25 \\
\hline Pimelea humilis & - & - & 78 & 25 \\
\hline Luzula sp. & - & - & 56 & - \\
\hline Acrotriche serrulata & - & - & 44 & 25 \\
\hline Geranium sessiliflorum & - & - & 89 & 25 \\
\hline Cymbonotus lawsonianus & - & - & 11 & - \\
\hline Plantago varia & - & - & 33 & - \\
\hline Helichrysum scorpioides & - & - & 11 & - \\
\hline Aira sp. & - & - & 56 & 25 \\
\hline Banksia marginata & - & - & 22 & - \\
\hline Rumex acetosella* & - & - & 44 & 25 \\
\hline Dichelachne crinita & - & - & 11 & - \\
\hline Melaleuca ericifolia & - & - & 11 & 100 \\
\hline Scleranthus biflorus & - & - & 11 & - \\
\hline Carex sp. & - & - & 11 & - \\
\hline Centaurium sp.* & - & - & 11 & - \\
\hline Glycine clandestina & - & - & 11 & - \\
\hline Exocarpus strictus & - & - & 11 & - \\
\hline Leptospermum lanigerum & - & - & - & 25 \\
\hline Acacia verticillata & - & - & - & 50 \\
\hline Helichrysum dendroideum & - & - & - & 25 \\
\hline Rubus parvifolius & - & - & - & 25 \\
\hline Cassytha melantha & - & - & - & 25 \\
\hline Bursaria spinosa & - & - & - & 25 \\
\hline Moss sp. & - & 100 & 100 & 25 \\
\hline Fungi sp. & 20 & 14 & - & 50 \\
\hline Litter & - & 14 & 56 & - \\
\hline Lichen sp. & - & 14 & 11 & - \\
\hline
\end{tabular}

* exotic species 


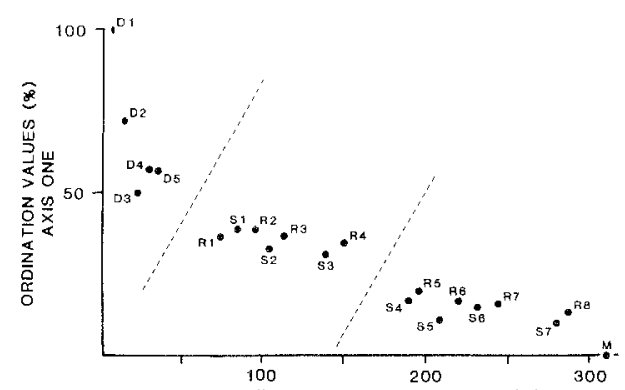

FIG. 4 -Relationship between ordination scores on axis one and distance from the high water mark.

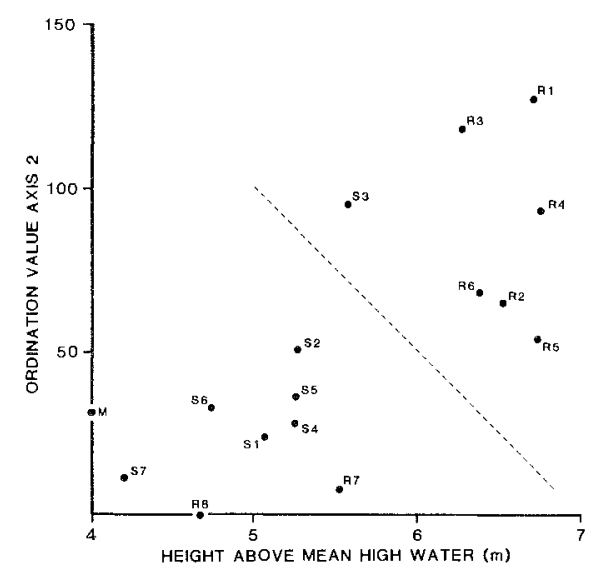

FIG. 5 - Relationship between ordination values on axis two and height above mean high tide mark.

distance inland (fig. 4). The natural logarithm of the distance inland along the transect is highly correlated with cumulative species number ( $r=0.945 \mathrm{p}<0.001)$. Salt spray deposition is a power function of distance inland (Ranwell 1972), suggesting that the major influence on species occurrence might be exposure to salt spray. However, edaphic variation is also strongly directional. Ordination scores on the first axis are not as strongly correlated with surface $\mathrm{pH}$, soil organic content or calcium carbonate content as with the natural logarithm of distance inland $(\mathrm{r}=0.55$ $\mathrm{p}<0.01, \mathrm{r}=-0.66 \mathrm{p}<0.001$, and $\mathrm{r}=-0.798$ $\mathrm{p}<0.001$, cf. $\mathrm{r}=-0.958 \mathrm{p}<0.001$ ). However, soil nutrient conditions cannot be dismissed as a major influence on directional vegetation change, especially given the sharp break in species distribution patterns at the new sand-old sand boundary in the ridge/swale complex. The proportion of bare ground, and thus potentially mobile sand, may be important in limiting species establishment (Ranwell 1972: 51). The correlation coefficient between sand cover and the cumulative species number $(r=-0.843 p<0.01)$ is consistent with this hypothesis.

The second axis of the ordination is most closely related to topography, as indicated by height above the mean high-water mark. All sites in the ridge/ swale complex above $5.6 \mathrm{~m}$ have ordination scores in excess of 51 , while all such sites below $5.6 \mathrm{~m}$ have ordination scores less than this figure (fig. 5). Height above sea level is probably related to moisture availability in the upper part of the soil. This hypothesis is supported by the relationship between moss cover and height above sea level in the ridge/swale complex $(r=-0.720, p<0.001)$. Consistent moisture availability and occasional waterlogged conditions are almost certainly associated with the $M$. ericifolia swamp forest, the only place where the water table is reached within $2 \mathrm{~m}$.

\section{Vegetation Change}

Buried soil horizons and dune morphology indicate that the sand dune system was dynamic even before European settlement. The vegetation undoubtedly responded to such changes and to past variations in Aboriginal land use.

There is no direct evidence of the nature of the Bakers Beach dune vegetation before 1800 . The remains of dead Eucalyptus viminalis, and some living individuals of Casuarina stricta, Bursaria spinosa and Banksia marginata indicate that communities dominated by trees could potentially occupy most of the ridge/swale complex. The use of the ridge/swale complex for stock grazing seems to have inhibited regeneration of these tree species, and to have turned most of the area into a sparse herbland dominated by Lomandra longifolia and Pteridium esculentum as reported elsewhere (Brown \& Bayley-Stark 1979, Brown 1980, Dickinson \& Kirkpatrick 1986). Cessation of stock grazing was followed by fuel accumulation and a fire which may have led to a further retreat of the eucalypts. Fire-stimulated germination of seeds of Acacia sophorae over most of the complex thus gave rise to its present dominance. However, A. sophorae is a short-lived species which relies on disturbance for its regeneration (Hazard \& Parsons 
1977). In the absence of another fire or mechanical disturbance through dune movement, it is likely to be replaced as a dominant on the ridge/ swale complex by Leucopogon parviflorus, a bird dispersed species capable of continuous regeneration without disturbance (Hazard \& Parsons 1977). If fires recur on the dune system, the nature of the resulting vegetation will be highly dependent on fire regime and the interaction of fire with grazing (cf. Brown 1980). In the early part of the nineteenth century, many of the coastal dune systems that are now covered by scrub or herbland were covered by scattered trees and tall shrubs over native tussock grass (Plomley 1966, Stockton 1982). Where tree species survive at Bakers Beach, such vegetation could be induced by low intensity burning at a frequency sufficient to prevent successful establishment of species such as Acacia sophorae, which rely on regeneration from seed rather than vegetative recovery. Occasional severe fires, however, will encourage the latter species and prevent growth of tree seedlings.

The large herbivore density on the dunes is such that Spinifex hirsutus open-grassland on the foredune is cropped to lawn height by wombats, and scat densities are high throughout the ridge/swale complex. The potential influence of these herbivores on tree and shrub seedling regeneration is hard to predict, although it is known that the effects of herbivores can be dramatically increased by other sources of disturbance such as fire (Leigh \& Holgate 1979, Dickinson \& Kirkpatrick 1986). Heavy grazing pressure may favour herbs and grasses rather than shrubs (Dickinson \& Kirkpatrick 1986). There is little likelihood that even severe fire will dramatically reduce herbivore numbers, as the main focus of grazing activity is on fire-resistant former paddocks to the rear of the dunes.

\section{Context and Conservation Importance}

Although most of the Bakers Beach sand dune vegetation is in a less pristine state than that of Rheban Spit (Bowden \& Kirkpatrick 1974) or the Maria Island isthmus (Brown \& Bayley-Stark 1979), enough elements of the original vegetation remain to show that, with a few minor exceptions, zonation is similar. Bakers Beach, unlike the other two systems, has not been invaded by marram grass (Ammophila arenaria), and the native sand-binder is Spinifex hirsutus rather than Festuca littoralis. The swamps in southeastern Tasmania are dominated by Melaleuca squarrosa rather than
M. ericifolia. However, the three areas lack the Victorian element of coastal sand dune species present in the far northeast and northwest of mainland Tasmania (Kirkpatrick, in press).

The reservation status of the vegetation complex found on coastal sand dune systems is relatively poor, because of the demand for such areas for agricultural and recreational (shack) development. Thus, the Bakers Beach area, despite its present degraded state, is an important area for long-term conservation of sand dune vegetation and its associated fauna. It is a valuable area for location of permanent monitoring plots and exclosure plots, to record vegetation change and assess the impact of fauna in an apparently dynamic system.

\section{ACKNOWLEDGEMENTS}

Data collection and analysis was a joint project of Helen Cray, Steven Cleaves, Tina Duncan, Jenny Hough, Alan MacFayden, Ray McKendrick, John Megalos, Mike Kennan, Vicki Lee Thomas and the authors. Denis Charlesworth assisted with laboratory analysis. Dr Guus van der Geer drew the figures.

\section{REFERENCES}

BARSON, M.M. \& CALDER, D.M., 1981: The vegetation of the Victorian coast. Proc. R. Soc. Vict. 92: 4-65.

Bowden, A.R. \& KirkPATRICK, J.B., 1974: The vegetation of Rheban Spit, Tasmania. Pap. Proc. $R$. Soc. Tasm. 108: 199-210.

BRown, M.J., 1980: The vegetation of the Mt Cameron West Aboriginal Site. Pap. Proc. R. Soc. Tasm. 114: 21-34.

Brown, M.J. \& Bayley-Stark, J.H., 1979: Vegetation of Maria Istand. Wildl. Div. Tech. Rep. 79/1. Tasm. NPWS: 99 pp.

Bureau of Meteorology, 1979: CLIMATIC SURVEY TASMANIA, REGION 3 NORTHERN. Department of Science and the Environment, Canberra: $64 \mathrm{pp}$.

Canfreld, R., 1941: Application of the line interception method in sampling range vegetation. J. Forest. 39: 388-394.

CuRTIS, W.M., 1963: THE STUDENT'S FLORA OF TASMANIA, PART II. Government Printer, Hobart.

CuR'T1S, W.M., 1967: THE STUDENT'S FLORA OF TASMANIA, PART III. Government Printer, Hobart.

Curtis, W.M. \& Morris, D.I., 1975: THE STUDENT'S FLORA OF TASMANIA, PART I. 2nd edition, Government Printer, Hobart.

Davies, J.L., 1978: Beach sand and wave energy in Tasmania. In Davies, J.L. \& Williams, M.A.J. (Eds): LANDFORM EVOLUTION IN AUSTRALASIA. Oxford University Press, Canberra: 158-167. 
Davis, C., 1940: Preliminary survey of the vegetation near New Harbour, Tasmania, Pap. Proc. R. Soc. Tasm. 1940: 1-90.

Drckinsoy, K.J.M. \& Kirkpatrick, J.B., 1986: The impact of grazing pressure in clearfelled, burned and undisturbed eucalypt forest. Vegetatio 66: 133-136.

HazarD, J. \& Parsons, R.F., 1977: Size-class analysis of coastal scrub and woodland, Western Port, South Australia. Aust. J. Ecol. 2: 187-198.

HuL, MO., 1979: TWINSPAN - A FORTRAN PROGRAM FOR ARRANGING MULTI-VARIATE DATA IN AN ORDERED TWO-WAY TABLE BY CLASSIFICATION OF THE INDIVIDUALS AND ATTRIBUTES. Section of Ecology and Systematics, Cornell University, Ithaca.

Hill, M.O. \& Gauch, H.G., 1980: Detrended correspondence analysis: an improved ordination technique. Vegetatio 42: 47-58.

KiRKPATRICK, J.B., 1973: The vegetation of Sloping Island, Tasmania. Vict. Nat. 90: 313-321.

KrrkPATRICK, J.B., 1975: Phytosociological analysis of the vegetation of Lagoon Beach, Tasmania. Pap. Proc. R. Soc. Tasm. 109: 53-63.

KIRKPATRICK, J.B., in press: Dry coastal vegetation in southeastern Australia. In Mauri, E. van der (Ed.): $D R Y$ COASTAL ECOSYSTEMS. Elsevier, Amsterdam.

KirkPATRick, J.B. \& Harwood, C.E., 1983: Plant communities of Tasmanian wetlands. Aust. J. Bot. 31: $437-451$.

LadD, P.G., Ladiges, P.Y. \& Calder, D.M., 1976 : IDENTIFICATION OF THE LAND-BASED VEGETATION SURROUNDING THE GIPPSLAND LAKES AND LAKE TYERS. Ministry for Conservation, Victoria.
Leigh, J.H. \& Holgate, M.D., 1979: The responses of the understorey of forests and woodlands of the Southern Tablelands to grazing and burning. Aust. J. Ecol. 4(1): 25-45.

National Parks \& Wildolife Service, 1979: The impact of proposed pine plantations on wildlife in the West Tamar region, Tasmania. Unpubl. Rep. Tasm. NPWS.

Plomley, N.J.B., 1966: FRIENDLY MISSION. THE TASMANIAN JOURNALS AND PAPERS OF GEORGE AUGUSTUS ROBINSON 1829-1834. Tasmanian Historical Research Association, Hobart.

Ranwell, D.S., 1972: ECOLOGY OF SALT MARSHES AND SAND DUNES. Chapman and Hall, London.

Specht, R.L., 1970: Vegetation, In Leeper, G.W. (Ed.): THE AUSTRALIAN ENVIRONMENT, 4th edition. CSIRO and Melbourne University Press, Melbourne: 44-67.

SPECHT, R.L., 1972: THE VEGETATION OF SOUTH AUSTRALIA. 2nd edition, Government Printer, Adelaide.

Stephens, C.G. \& Cane, R.F., 1939: The soils and general ecology of the north-east coastal region of Tasmania. Pap. Proc. R. Soc. Tasm. 1938: 201-208.

STockton, J., 1982: Fires by the seaside: historic vegetation changes in northwestern Tasmania. Pap. Proc. R. Soc. Tasm. 116: 53-66.

Turner, J.S., Carr, S.G.M. \& Bird, E.C.F., 1962: The dune succession at Comer Inlet, Victoria. Proc. R. Soc. Vict. 75: 17-33.

WILlis, J.H., 1970: A HANDBOOK TO PLANTS IN VICTORIA, VOLUME I. 2nd edition, Melbourne University Press, Melboume.

(accepted 14 April 1989) 